\title{
Christian Theology in the Post-Modern Era
}

\author{
Paul F. Knitter
}

\begin{abstract}
Responding to postmodernity as one of the "signs of the times", Christians will have to carry out a balancing act between commitment to Christians will have to carrentess to those of others. This has implication for five areas of Christian theology and praxis. In theological method, we must recognise that all our beliefs are symbols that tell us something but must recognise that all our beliefs are symbols that tell us something but follow Christ as the Way that is open to other Ways. The Church will be . seen as a community that seeks a Reign of God that will always be more than what we now know of it. Ethics will be based on the principles and practice of non-violence: full commitment to moral convictions joined with practice of non-violence: full commint toward the convictions of others. Such a theology will need to be rooted in a spirituality in which we are "absolutely" committed to truths that we recognise are always "relative" a truly eschatological spirituality that is always "on the way".
\end{abstract}

\section{THE SIGNS OF OUR POST-MODERN TIME}

THE CHALlenge of CONNECTING "Christian Theology" with "the Post-Modern Era" is doubly difficult. One might think it is a simple matter of showing how theology has to respond to one of the "signs of the times": postmodernism. The problem is that it is perhaps more difficult to describe just what this sign of the times is than it is to work out a theological response.

Anyone who has struggled to get a hold of post-modernity, either to learn it or to teach it, knows what a slippery fish it is. Indeed, it bears the amorphous, purely historical name, "post-modernism" because of the difficulty of figuring out what else to call it. So I will not attempt to offer a textbook description of postmodernity - that is, a description based on a careful review of the literature. Rather, I should like to offer my own personal description of how I think we-especially those of us who live in the so-called developed world - are all postmoderns in our basic values or convictions - that is, in the way we see and feel and 
respond to the world around us. I find two convictions, two feelings, that throb in the core of what we can call "post-modern consciousness":

\section{(a) The Value/Necessity of Diversity}

We have come to realise that "manyness" is part of the way things work in the universe, that nature does not seem to make just one of anything, that diversity is the substance and energy of the creativity of the world whether we're talking about biological evolution or a football team. To put it in terms of the motto of the United States, we might say it is not so much a matter of e pluribus unum, but $e$ pluribus unitas. If we boil the many down to just one, that one is soon going to start to stagnate. We want a unity that preserves diversity rather than a oneness that consumes it.

Christians, and perhaps even more so Hindus, realise that this value or necessity of diversity applies even to God. Ours is a qualified monotheism. God is not just one; God is also many - for us, three, for the Hindus 33 million. As Edward Schillebeeckx puts it, we have come to realise and accept, albeit reluctantly for some, that diversity is not just a matter of fact; it is a matter of principle. ${ }^{1}$ It is not just the way things are but the way they should be - religious people would say, the way God made them and wants them.

\section{(b) The Danger of Absolutes}

All this provides the logical segue into the second defining ingredient of our post-modern consciousness: the danger of absolutes. Absolutes are dangerous because by their very nature, they squelch diversity. An absolute is a one and only; that means, an end point - a kind of huge ontological vacuum cleaner that sucks up all the unpleasant diversity. lying all over the floor and transforms it into a final whole.

But there are more than philosophical arguments that have lead our post-modern awareness to see the dangers of absolutes. History is the more convincing arbiter: we have seen what has happened to cultures and nations when any one of them held itself up as superior or the "manifest destiny" for all the others. Colonialism was and is grounded in the conviction that one culture has, or has been given by God, the one and only, or the absolute and superior, political or economic or religious system. ${ }^{2}$

So post-modern thinkers, in their jargon, warn us of the dangers of "meta-narratives" - ways of understanding the world that originate in

1. Edward Schillebeeckx, The Church: The Human Face of God (New York: Crossroad, 1990) 163.

2. For a contemporary review of this danger in our so-called post-9/11 world, see Charles Kimball, When Religion Becomes Evil (San Francisco: HarperSanFranciso, 2002). 
one place in the world and then are imposed on all other places. The real danger of universal truths, therefore, is not really that they are universal but that they are understood to exclude or set themselves above or absorb other universal truths. We shall return to this issue below.

\section{RESPONDING TO THE SIGNS OF THE TIMES}

\section{Our Theological Method}

In trying to respond to postmodernity as one of the most glaring and challenging signs of our times, I should like to make use of an understanding of theological method current among mainline Christian theologians. It is a method that tries to carry out Bernard Lonergan's understanding of theology as the mediator between a religious community and the culture in which it lives its life and carries out its mission. The theological task is a mutually clarifying and mutually criticising conversation between a religious tradition and its broader world. ${ }^{3}$ Realising that we cannot climb out of our religious or cultural skins, that we are "socially constructed" by both religion and culture to the point that it is often difficult to distinguish what is religion and what is culture, theologians still seek to distinguish the two and bring them into a conversation in which each one - the church and the world understand themselves more clearly and critically in light of the other.

\section{Criticising Postmodernity}

Trying to follow such a theological method will require us not just to listen and to learn from postmodernity, but also to criticise it. Without going into the kind of details that would be not only necessary but interesting to pursue, I shall first simply state what I believe to be the primary dangers of a too hearty or facile endorsement of post-modern values.

To use a familiar image, we can so insist on the value and beauty and unique particularity of each tree in the forest, that we forget, or can no longer really affirm, that the trees do, and must, form a forest. To insist only on particularity leads to isolation - the inability to connect, to communicate, to help and be helped. Philosophers call that solipsism. Post-modern diversity can lead to solitary confinement.

In so stressing diversity and particularity, postmodernity ends up with jigsaw puzzle pieces that are cut from a diversity of pictures - and so we cannot even begin the task of trying to put them together. To

3. Bernard J. F. Lonergan, Method in Theology (New York: Herder and Herder, 1972) xixii; David Tracy, Blessed Rage for Order: The New Pluralism in Theology (New York: Seabury Press, 1975) 43-56. 
draw once again on biology as mentor, postmoderns too easily forget that nature has not only produced incredible diversity but also incredible interconnectedness. No matter how different we are, we can - and must always find some way to connect and to communicate.

This leads to a second danger of postmodernity. If we cannot connect, if we cannot communicate and challenge each other, then each particular becomes its own absolute. What is true in my backyard is true for me but not for you; it is true because that's the way things are in my backyard. Philosophers would call this relativism. It is not only the case that truth is always socially constructed; it is a social construction. Truth will be different in each cultural or religious backyard, because each backyard determines - or comes to a consensus - of what truth is.

So it seems that in denying absolutes, postmodernity has a hard time keeping itself from those slippery slopes of relativism. Diversity becomes "anything goes". This, we well know, is the dominant concern of the Vatican about the post-modern insistence on pluralism. Pluralism for former-Cardinal Ratzinger, now Pope Benedict XVI, is a synonym for relativism. 4 He has good reason to be concerned.

\section{The Challenge of Postmodernity}

The challenge that postmodernity sets before Christian theology can be summarised as the complex but creative task of balancing two, apparently contradicting, fundamental options: commitment and openness.

We need a theology that balances commitment to what we are and know, with openness to others and to what we do not know. If we seek to balance these two qualities - qualities that must mark both our personal faith (fides) and the theological understanding that it seeks (intellectus) - we can fashion a theological conversation with postmodernity that will truly learn from post-modern insights and convictions without selling out to them and so slipping down the slopes of solipsism or relativism.

Openness takes seriously the value of diversity and the danger of absolutes and solipsism. Commitment provides a handrail that keeps us from those slippery slopes. In what follows, I propose to outline briefly but I hope clearly - what this balancing of openness and commitment might mean for five areas of our theological project: God-

4. See "Relativism the Central Problem for Faith Today", an address given by Cardinal Josef Ratzinger at a meeting of the Congregation for the Doctrine of the Faith with the presidents of the doctrinal commissions of the Bishops' Conference of Latin America, held in Guadelajara, Mexico, May 1996, Available at http://www.ewtn.com/library/CURIA/ RATZRELA.HTM. 
talk (or religious language), christology, ecclesiology, ethics, and spirituality.

\section{GOD-TALK-RELIGIOUS LANGUAGE \\ The Post-modern Challenge}

One of the greatest values, but also one of the nastiest dangers of Christianity, and especially of Roman Catholicism, is that we take language seriously. We believe that Divinity includes Logos (Word), or that the Ultimate communicates and speaks. Even more, we believe that this Logos or this divine-speaking becomes human and did so normatively in the human being of Jesus of Nazareth. And further, Catholics believe that this incarnation of the Divine Logos continues, in a limited but still real way, in the human community and institution called Church.

This makes for the sacredness of language: human words are understood to be vehicles of divine words. The words of the Bible, of the liturgy, of doctrine can convey not just the vision of God for the world, but the very experience of God's presence and life within us and in our community.

But, in contrast to the confident certainties of earlier times, postmodern awareness would immediately warn us today that the sacredness of language can easily become the idolatry of language. From the conviction that God has spoken to us, we conclude that God has said everything to us. We forget what we know: that because God is, as Karl Rahner insisted, schlechthinniges Geheimnis (Absolute Mystery), and because human language is always limited, no language, no doctrine can capture the fullness or the finality of God. While our God-talk and church-talk, revealed through Christ Jesus, tells the truth about God, it can never tell us the whole truth about God. While it is universal and so must be shared with all peoples, it is not absolute and so exclusive of other or of further truth. Those, especially church leaders, who forget this leave themselves open to the temptation of allowing the truth that God has spoken to them to become a means for controlling the community. Truth is always power; and if we make that truth absolute, we have absolute power.

This, then is the challenge for theology: how to live out to the full a commitment to the truth of what our scriptural, liturgical, doctrinal language is telling us; how to extend that commitment "ad gentes" - to all nations - in announcing it to others, while at the same time remaining open to other languages, other words; how to hold fast to the truth of what our language tells us about God without absolutising it 
into all that can be said of God; how to speak our own Christian language without jeopardising a capacity to learn to speak other religious languages.

\section{Responding to the Post-modern Challenge: All Religious Language is Symbolic}

One way to work at balancing commitment to our own religious language and beliefs with openness to what is "more than" this language lies in taking much more seriously something that is standard Christian teaching: that all - all - our language about God is symbolic, analogical, metaphorical, sacramental.

As Karl Rahner and Paul Tillich make clear, a symbol truly participates in what it symbolises; it is not just a sign, a pointer. The symbolised, in this case the Divine, is truly present in and as the symbol, because it participates in the symbol. But the symbol can never be simply identified with the symbolised. While the Divine is truly immanent in the symbol, the Divine always, by its very nature, remains transcendent to the symbol. There is always more that can be symbolised. Or, in the beautiful and powerful image from Buddhism, all our religious language, all our symbols, are fingers pointing to the moon; but the finger, while it inherently points to the moon, is never the moon itself. All of our language - not just the poetry of the Bible but also the philosophical concepts of the Councils - are fingers pointing to the moon, not the moon itself. While we must always take this language seriously, we must be wary of taking it literally. Our religious language may provide us with truth on which to build our lives. But it is truth from which we can and must take further steps.

\section{CHRISTOLOGY \\ The Post-modern Challenge}

The post-modern challenge for christology is crystallised in a new awareness of religious pluralism. How to witness to Christ and the Gospel in such a way as to affirm the diversity - and that means the value, the validity - of other revelations, revealers, religions? We must find a way of proclaiming the distinctiveness of Jesus without denigrating the distinctiveness of Buddha. Or more personally: how to be fully committed to Christ and fully open to what God may be trying to tell us in Krishna.

A happy and encouraging note on this challenge is that the Roman Catholic Church, not known for its innovative alacrity, has been a pioneer among Christian churches in taking this challenge seriously. What the Second Vatican Council - and later what the encyclical 
Redemptoris Missio and the Declaration on Dialogue and Proclamation ${ }^{5}-$ had to say about other religions and about the necessity of dialogue are truly watersheds in the history of Christianity. ${ }^{6}$

But more recent signals from the Vatican seem to indicate that Church officials are frightened by what has been entering the Church through the windows that Vatican II opened to other religious communities. Recent statements, such as the Declaration of the Congregation for the Doctrine of the Faith Dominus Iesus (On the Unicity and Salvific Universality of Jesus Christ and the Church [2000]), and actions against theologians such as Jacques Dupuis, Tissa Balasuriya and Roger Haight, indicate that theologians and communities (especially in Asia) are moving, in the Vatican's estimation, far too quickly on the currents released by the watershed of Vatican II in regard to other religions. The concern, as already noted, is a valid one: is the new affirmation of religious diversity and the new questioning of Christ as absolute saviour leading to relativism?

\section{Responding to the Post-modern Challenge: A Truly Sacramental Christology}

In order to respond to this post-modern challenge, I would suggest that it is possible to reach a more balanced understanding of Jesus' salvific role by drawing more on the Johannine writings of the New Testament (and not just on Paul). In Catholic terminology, this will enable the development of a sacramental soteriology (Protestants prefer the term representative) in order to balance the dominant constitutive soteriology. To summarise (without, I hope, oversimplifying) the difference: as a sacramental cause, Jesus saves by revealing; as a constitutive cause, he saves by fixing.

As the constitutive cause of salvation, Jesus is generally understood to have effected something, or to have done something which in some way repaired, or bridged, the rift between God and humanity. His death and resurrection opened the gates of heaven, or reconnected humans with God, and so constituted or established the possibility of salvation for everyone.

As a sacramental cause of salvation, Jesus is understood along the lines of traditional sacramental theology: in his life, death, and resurrection he shows or reveals what is already there in the world but not really available to us because we do not see it, or are not aware of it, or fail to

5. For texts and commentary on both documents, see William R. Burrows (ed.), Redemption and Dialogue: Reading Redemptoris Missio and Dialogue and Prodamation (Maryknoll, NY: Orbis Books, 1993).

6. See Paul F. Knitter, Introducing Theologies of Religions (Maryknoll, NY: Orbis Books, 2002) $75-79$. 
trust it: the ever-present, affirming, accepting, forgiving love of God. Jesus re-presents, embodies, symbolises the universal, active presence of God - allowing that Divine Presence or Spirit to transform human lives in a manner not possible without him.

A constitutive and a sacramental christology or soteriology are not necessarily at odds with each other. Yet the differences between them are stark when applied to the question of openness to other religions. A constitutive cause is intrinsically singular. Once something is fixed, it does not need to be, or it cannot be, fixed again. But a sacramental cause is at least potentially open to being multiple. What is revealed at one point in history, or in one culture, or in one set of particular human needs, can be revealed very differently, but just as effectively, in another culture or historical context. And when what is being revealed is the incomprehensible, ever-rich and creative Mystery of God, then a variety of revelations, or sacraments, of this Divine mystery not only makes sense but is to be expected.

Such a sacramental christology or soteriology calls for full commitment to Christ; but it also calls for total openness to other possible sacraments. In the words of John Cobb, Christ is the Way that is open to other Ways. ${ }^{7}$

\section{ECCLESIOLOGY}

\section{The Post-modern Challenge}

The post-modern challenge for ecclesiology is similar to that for christology: how to understand the nature, and especially the mission of the church in such a way as to remain fully committed to the necessary role this community plays both in the life of its members and in the life of the world, while at the same time remaining open to what might be the necessary role that other communities and other traditions are to play in what we call the "economy of salvation".

For most of its history the church (perhaps for understandable historical-cultural reasons) has had a ruthlessly exclusive ecclesiology. The notion of "baptism of desire", devised after all those unbaptized pagans were discovered in the "New World", may have allowed goodwilled pagans to enter the back door of heaven. It never allowed their religions to bring them to that back door.

For many post-modern Christians, Vatican II's affirmation of the value of other religions, watershed though it be, still limps. It does not allow sufficient openness to others, since in the end the religions, for all

7. John B. Cobb Jr., "Beyond Pluralism", in Gavin D'Costa (ed.), Christian Uniqueness Reconsidered: The Myth of a Plutalistic Theology of Religions (Maryknoll, NY: Orbis Books, 1990) 91 . 
the "truth and goodness" that they may contain, constitute a praeparatio evangelica (a preparation for the Gospel). For Catholics this means, in effect, a praeparatio ecclesiastica: the role of the religions is to serve as ushers into the Christian community.

However one responds to this post-modern challenge to ecclesiology, it would seem that in order to remain faithful to Christian tradition and experience, the response has to avoid simply levelling off all the religions, claiming that all of them, together with Christianity, are "ways of salvation" heading in the same direction albeit along different paths. Such a view would offend the distinctiveness not only of Christianity, but of the religions themselves. It would boil all the religions down to a salvific tapioca.

\section{Responding to the Post-modern Challenge: A Regnocentric Ecclesiology}

I suggest that a response to this post-modern questioning of our image of church should be closely linked to the sacramental christology just outlined. If we try to be more specific about what Jesus-theSacrament reveals, one answer would have to be the Kingdom or Reign of God. New Testaments scholars may not be able to agree on much about the historical Jesus, but on one issue they resonate: that his message was centred on the Reign of God. This is what Jesus wanted people to believe in, hope and work for. Yes, he wanted them to believe in God, but if this God did not call and inspire them to love each other, to treat each other justly, to respond to the needs of each other, and to work for a society in which people would really live this way - then it was not the God of Jesus. A God without the Reign of God was for Jesus a false God.

A theology that is as regnocentric (the Latin seems less sexist) as Jesus' own proclamation would affirm the role, the necessary role, of the church in envisioning, understanding, and working toward this "new world order" called the Basileia tou Theou. But since such a regnocentric ecclesiology would also affirm - as Pope John Paul II has recognised ${ }^{8}-$ that the Reign of God is larger than the church and that the church is a servant of the Reign of God, this view of the church would also be open to what might be the very different, but also very necessary, contributions that other religious or secular communities might be able to make to fashioning this new way of living together on earth.

In a regnocentric ecclesiology, the primary motivation, goal, and guideline in the Christian dialogue with other religions would not be to

8. Redemptoris Missio, \# 18, 20, 35, 59. See also Jacques Dupuis, "A Theological Commentary: Dialogue and Proclamation", in Redemption and Dialogue, 148-50. 
convert them to the Christian church, nor even, we can add, to bring them to accept Jesus as their only Saviour. Rather, Christians engage other believers first of all in order to work with them to further God's reign on earth, to contribute to a world of greater love, peace, justice. Certainly, Christians will want to, and will need to, bear witness to other believers about how Jesus and his God can make this reign of love and justice possible and workable. But followers of Jesus will also know that "those who are not against us are for us" (Mark 9:40), and that therefore these others may have much to teach Christians about the reign of God.

I believe that this symbol of the reign of God is clear enough to "point to" a common destination for all religions, but also broad enough to affirm the really different, distinctive, and universally urgent ways in which the various communities contribute to this common goal of greater well being of humans and all sentient beings.

\section{ETHICS}

\section{The Post-modern Challenge}

Perhaps the area of Christian theology in which postmodernity sends its most rattling and mind-bending challenges is that of ethics. For it is here, in the realm of morality, that absolutes are most sharply formulated and staunchly defended: "Thou shalt not....Thou shalt". Moral absolutes, postmoderns warn us, are some of the most devastating absolutes that religion has produced, for moral claims do not only demarcate between those who are right and those who are wrong, but also between those who are good and those who are evil. While mistakes might be tolerated, evil must be obliterated. Thus, there is a particularly urgent need to balance commitment to our moral principles with openness to the moral principles of others.

$\mathrm{Ah}$, but here's the rub. In the realm of ethics, such a balancing requires a de-absolutising of ethical claims; and that often seems well nigh impossible. Langdon Gilkey, in an article as far back as 1987, gets to the nub of the reason why: we live in a world in which, if we look beyond our suburban walls and Sunday football games, we see events or practices or policies that most of us feel, and so judge, to be intolerable. Dehumanising poverty, starvation, torture, violence (domestic, sexual, military), environmental devastation, terrorism, imperialism. Before the image of starving babies, or children maimed by a meandering collateral bomb, or women raped en masse by ethnic armies, or bodies scarred by torture, or dead fish floating on polluted river - there surges within us a spontaneous, inexorable "No! This should not be." Such feelings, Gilkey observes, have an absolute quality about them. And they therefore demand some kind of an absolute response - a response which brooks 
no relativising "maybe" or "in my opinion" or social construction. 9 How then can we work out our proposed balance between commitment and openness in the realm of ethics?

\section{Responding to the Post-modern Challenge:}

An Ethical Methodology and Practice of Non-violence

In trying to explore a response to the post-modern challenge for Christian ethics, I suggest that such a response be worked out along the lines of what we can call an ethical methodology and practice of nonviolence. If we apply the basic principles of Gandhi's and Martin Luther King's non-violent resistance to the way we come to make ethical claims (the methodology part) and to the way we live such claims (the practice part), I believe we can achieve our desired balance between commitment and openness in the area of ethics.

Adopting Gandhi's and King's practice of non-violent resistance certainly allows, even requires us to take, like them, clear, strong, adamant, contrary positions. People will know where we stand and what we are for. And we will be ready, ideally, to suffer, even die, for these claims, these ethical stands. But at the same time, we will do all this non-violently. And that means not just refusing to do physical or even verbal harm to those who disagree and oppose us; it means also, and fundamentally, that we will respect them, care for them, listen to them, - love them. The heart of ahimsa or nonviolence is bhakti or compassion.

In other words, we take absolute ethical stands, but we do so in a way in which we remain connected with or still in relation to those who oppose us - or those whom we oppose. As Miroslav Volf puts it, our opposition to others never leads to their exclusion; in opposing them we, paradoxically, embrace them..$^{10}$ So we are committed to the point of death to what we hold to be true and right, but we are open to those who do not agree with us, or seek to struggle against us. In opposing the evil that we think some people do, we will never consider them evil, objects of hate or scorn.

But we follow this methodology of nonviolence, not just as a tactic, not just as a way of winning our opponents over or converting them to what we strongly believe to be the "good" way of acting. We open ourselves to others not just out of compassion, but also out of humility. By this I mean that as strongly as we are committed to what we stand for,

9. Langdon Gilkey, "Plurality and Its Theological Implications", in John Hick and Paul F. Knitter (eds.), The Myth of Christian Uniqueness: Toward a Pluralistic Theology of Religions (Maryknoll, NY: Orbis Books, 1987) 44-50.

10. Miroslav Volf, Exclusion and Embrace: A Theological Exploration of Identity, Otherness, and Reconciliation (Nashville, TN: Abingdon Press, 1997). 
we also realise that there is always more to learn, that there may be other ways of understanding this ethical issue, that we may be missing something - even, that we may be wrong! And therefore, we must also listen to those who oppose us, understand their views, their fears, their commitments. This is not easy. I dare say that only love makes it possible. Such a non-violent ethics, therefore, does not just "speak truth to power"; it speaks truth to power with love.

\section{Conclusion - Spirituality}

In conclusion I should like to say, something about the kind of spirituality that seems necessary to sustain and animate the postmodern theology that I have tried to sketch.

To be truly committed and open in Christian discipleship; to know and feel that all our beliefs are symbols that tell us something but never everything about God, self, world; to follow Christ as the Way that is essentially open to other Ways; to live and act in a community that seeks a Reign that will always be more than what we now know of it; to be faithful to our ethical convictions in compassion and respect toward the different convictions of others: all this calls for the foundational support of a particular kind of spirituality.

It is a spirituality which, to put it tersely, calls for absolute commitment to relative truth. We must give ourselves fully to the marvellous, urgent truth that God has made known in Christ Jesus - as fully as did, for example, Archbishop Oscar Romero (1980) or the six Jesuits (1989) killed in El Salvador - even though we know that this revealed truth itself, or certainly our grasp of it, is partial, limited, open to clarification and expansion. Full, personal, existential giving over of ourselves to truth that we know only partially, incompletely, fragmentarily will involve a bold, adult spirituality.

Such commitment makes clear what is really meant by the word we use so often - faith (fides, pistis). Faith means trust. Trust means giving, but not knowing, fully. We trust, we give ourselves over to what we can see only through a glass darkly. A colleague of mind calls this a wager into the abyss. My wife Cathy describes it with the Buddhists as a stepping into Groundlessness. My Christian sensitivities lead me to prefer something more positive, though I hope without minimising the need to trust, to let go. Christian faith is what it was first called: a "hodos", a way, a journey. In other words, a post-modern Christian spirituality that will sustain a post-modern Christian theology will be an eschatological spirituality.

We are pilgrims, always on the way, not yet there. While we know that this Reign of God announced by Jesus and vivified by the Spirit is 
already with us, we also know that it is not yet with us. We are fully committed to it, but we have to balance that commitment with an openness to what is yet to come.

And it will come, or we will understand it better, by being open to God's diversity - both the diversity of God's self and the diversity of God's creation. That diversity, and that future and fuller grasp of who God, Christ, Church is, will come from the other. That is, from those who are different from us. To practise a post-modern Christian faith and develop a post-modern Christian theology we have to be as faithfully committed to our own tradition as we are dialogically open to that of others. 